\title{
From Developmental State to Developmental Society?: The Role of Civil Society Organizations in Recent Korean Development and Possible Lessons for Developing Countries*
}

\author{
THOMAS KALINOWSKI ${ }^{* *}$
}

In the 1980 s and 1990 s, rapid market oriented reforms, liberalization and privatization ("shock therapy") in developing and transformational countries caused economic and social problems that began to undermine the legitimacy of political democratization and market reforms itself. Scholars in the field of transformation and development theory found that market coordination alone was not able to fill the void left by a weak or weakening state. In this essay, we look at the case of Korea to find out if an active civil society can substitute functions of the withdrawing developmental state since the 1980 s. We show that civil society organizations (CSOs) in Korea have been relatively effective in influencing political processes, shaping public opinion, compensating the weakness of political institutions, and contributing to general development. Korean CSOs achieved this remarkable impact despite substantial organizational problems and a relatively unfavorable socioeconomic and political environment. This effectiveness and the synergy between state and civil society make Korean CSOs very interesting to study for development scholars. Korea might offer some valuable lessons on how to improve advocacy CSOs in an unfavorable environment similar to that of many developing countries.

Keywords: Civil Society, Civil Society Organizations, NGOs, Development, Democracization, Korea

This work was supported by the Ewha Womans University Research Grant of 2007. The author would like to thank Hajeong Lee, Younghui $\mathrm{Na}$, Shengnan Wang and Ahyoung Kim for providing research assistance for this paper. Thanks also to Hyeyun Park and two anonymous reviewers who provided valuable comments on earlier versions of this draft.

* Assistant Professor Graduate School of International Studics, Ewha Womans University 11-1 Dachyun-dong, Seodaemun-gu, Seoul, 120-750, Korea; Tel: +82-2-3277-6636; Fax: 82-2-365-0942;

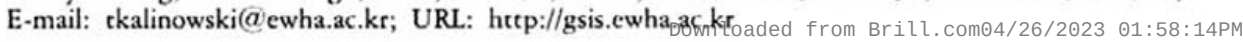




\section{INTRODUCTION}

The role of civil society in economic development and democratization has 1 been discussed at least since de Tocqueville, but there has been a boom of civil society literature since the 1990s. ${ }^{1}$ This boom can be explained by disappointments with free market capitalism in the U.S. and Europe on the one hand, as well as the collapse of centrally planned economies in the Communist Block, and the dismantling of developmental states in East Asia on the other hand.

Communitarian scholars in the West lamented the loss of civil society that was displaced by materialistic drive, corporate control ("Mc World"), mass media consumption and atomization ("Bowling alone") (Barber 1995; Putnam 1995). More interestingly for our purposes in this essay, scholars in the field of transformation and development theory soon found that market coordination alone could not substitute a withdrawing state (Bratton 1989; Evans 1996; World Bank 1997, 2005). In the 1980s and 1990s, rapid market oriented reforms, liberalization and privatization ("shock therapy") in developing and transformational countries had devastating economic and social consequences that began to undermine the legitimacy of market reforms and political democratization. Civil societies in East Asian and Eastern European countries were weak because authoritarian developmental (East Asia) or socialist (Eastern Europe) states had suppressed opposition parties, and crowded out civil society organizations. When the authoritarian states collapsed, this civil society vacuum filled with big business interest, populist politicians, and even corrupt, oligarchic structures. A possible remedy was the strengthening of civil society organizations (CSOs) to occupy the vacuum left by the authoritarian state.

In this essay, we look at the case of Korea to find out if an active civil society can fill the gap created by a withdrawing authoritarian developmental state. Until the 1980s, Korean development was relatively successfully achieved by a military dictatorship that planned and implemented a ruthless industrialization strategy, mostly carried out by privately owned big industrial conglomerates (chaebol) (Evans 1995; Kim 1997; Woo-Cumings 1991; contributions in WooCumings 1999). The primary goal of the developmental state was economic growth while consumption interests of labor and profit interests of business were suppressed. Since the 1990s, CSOs have supplemented the withdrawing developmental state by taking over coordination functions that work bottom up, and involve the engagement of ordinary citizens in the development process. CSOs smoothen market processes, channel political discontent, balance the power of big business, and act as an intermediary institution between the society and formal state institutions. In short, we can observe a transformation from a developmental state to a much more comprehensive developmental society. CSOs in Korea have been very effective in the sense that they have had a substantial 
impact on development, in particular, political processes despite organizational problems and a relatively unfavorable socioeconomic and political environment. This effectiveness and the synergy between state and civil society (Evans 1996) make Korean CSOs very interesting to study for development scholars. When we analyze CSOs in Korea, we focus on advocacy CSOs that play an important role in supplementing a weak political party system (Lee 2009) by organizing public interests and shaping public opinion. ${ }^{2}$

This essay is organized as follows. In section 2, we provide a brief overview over the development of the Korean civil society through the lens of relevant theoretical approaches. In section 3, we evaluate the effectiveness of CSOs by looking at their activities and their strengths and weaknesses. In section 4, we highlight the state-civil society synergy that supplemented the withdrawing developmental state. In section 5, we discuss possible lessons for developing countries that face challenges from a weak state, or economic liberalization and deregulation. Section 6 concludes this paper.

\section{THE DEVELOPMENT OF KOREA'S CIVIL SOCIETY}

In order to understand the importance of civil society in Korea, it is first necessary to review its weakness in the past. After independence in 1945, the Korean developmental state overcame obstacles to development by destroying the pre-industrial civil society through land reforms. Until the 1970s, the military dictatorship tried to overcome the Confucian rules that had provided an ultra-conservative glue for the Korean civil society over centuries. Since the 1960s, the Korean state pursued a capitalist planned economy with a professional bureaucracy, state control over the financial sector, and active industrial policies (Evans 1995; Kim 1997; Woo-Cumings 1991; contributions in Woo-Cumings 1999). Labor interests were suppressed and profit interests of businesses were subordinated to the "growth first" policies. Korea was ruled by an authoritarian and relatively autonomous developmental state in which the government teamed up with big business as a junior partner. Such a regime left little room for civil society activities except for outright political opposition to topple the government. Migdal named Korea as one of the rare strong states that are an exemption from the combination of "strong societies and weak states" prevailing in the post-colonial developing world (Migdal 1988, 269). However, state-civil society relations are not static, and since the 1980s the chaebol (huge business conglomerates) began to emancipate themselves from state custodianship (Kim 1993). The huge business conglomerates massively expanded during the government-planned heavy and chemical industry development since the 1970s. Due to their size, the chaebol became less dependent on the state since the 1980s. They even started pressuring the government for more economic freedom and the government initiated the 
first economic liberalization policies. Most notably the government privatized financial institutes in the 1980s, abandoned the five-year plans, and liberalized the capital account in the 1990s. The market mechanism began substituting some of the coordination within the society that was previously managed by the state. At the same time student, labor, and citizen groups struggled for democratization and political freedom by overthrowing the military dictatorship in 1987 (Kim 2001; Koo 2002). The democracy movement formed the Student groups, and labor unions formed the nucleus of the civil society in Korea. Since the beginning of democratization, they diversified from the single issue of removing the military dictatorship to a diversified agenda. The three largest civil society groups Citizen Coalition for Economic Justice (CCEJ) with currently 35,000 members, Korean Federation for Environmental Movement (KFEM) with 45,000 members, and People's Solidarity for Participatory Democracy (PSPD) with almost 10,000 members, were founded in 1989, 1993, and 1994 respectively (CCEJ 2009; KFEM 2009; PSPD 2009). The CCEJ and PSPD became almost party-like organizations with mass membership covering a broad variety of issues like human rights, corruption, environment, and economic justice. More precisely, they filled the void left by weak party structures particularly on the left of the political spectrum. During the presidency of Kim Dae Jung (1998 2003) and Roh Moo Hyun (2003-08), the situation of CSOs changed dramatically and civil society groups mushroomed with the support of the government. Both presidents came to power from the opposition against the established conservative party/chaebol coalition. They actively supported civil society groups to balance the power of vested interest and to build their own grass root support.

However, the role of CSOs goes far beyond the promoting formal political democratization and a political role in the narrow sense as grass root support for the progressive/business critical politicians and parties. CSOs also play in important role to create an alternative public spheres and counter the cultural hegemony (Gramsci 1992) of the chaebol-media-conservative party complex that dominated the Korean "Chaebol Republic" (Kim 1997) from the 1980s until 1997.

Civil society groups have not only filled the gap left by week political parties, they have also taken over roles that are traditionally the arena of labor unions. Labor union organizations in Korea are not as weak as party organizations, but they are heavily concentrated in the large chaebol companies and organized on the company level. They are strong in negotiating wage increases for their members, but are prone to collusion with management and remain politically weak without their own vision for the progress of Korean society in general. Umbrella labor union organizations and the Democratic Labor Party exist, but have little control over the company labor unions. Again, civil society organizations have filled the gap and developed demands for economic policies that would be an alternative to the chaebol-friendly market liberalization. From the beginning, 
an important goal of civil society groups was to dismantle or at least curb the power of the chaebols that flourished under economic liberalization and free access to international financial markets (Kalinowski and Cho 2009). In this sense, CSOs can be understood as part of a Polanyian self-protection mechanism of the society against runaway markets (Polanyi 2001; Silver and Arrighi 2003).

With the election of the progressive Roh Moo Hyun in 2002, conservatives who still tend to believe that they are the "natural rulers" of Korea realized that the election of Kim Dae Jung was not an accident but that they would be excluded from power for another five years. They realized that party mobilization and support by the main newspapers was not enough to reclaim power, but that they would have to counter the left in the civil society as well. Consequently, in 2004 , the "new right movement" was founded by conservative intellectuals to balance the civil society arena and engaged in their own endeavor to influence political opinion (Han 2007). They not only criticized the progressive administration of then-President Roh, but also the conservative party that they perceived as corrupt and unable to attract the masses that are needed to win elections in a democracy. Most importantly, the new right distances itself from the old "developmental state" right, not just by championing democracy but also by opposing state intervention into the economy and by demanding an acceleration of free market reforms (Liberty Union 2009). They, thus, form a counter-counter movement and oppose those parts of the civil society that try to slow down the "pendulum" from swinging too far in the direction of unregulated markets. Since the conservative Lee Myung Bak became president in 2009, the new right is thriving although it remains to be seen if their free market ideology will appeal to the public beyond a limited number of economic elites and intellectuals.

\section{CSO EFFECTIVENESS: STRONG IMPACT IN A CHALLENGING ENVIRONMENT}

It is extremely difficult to measure civil society, but it is possible to grasp their role, as well as their strengths and weaknesses. This is done by combining a literature review with the comparative perspective of the Civil Sociery Index that is conducted by CIVICUS, and compares the state of civil society in 53 countries (CIVICUS 2009; Heinrich 2007). ${ }^{3}$ If not stated otherwise, the following evaluation of Korean CSOs is based on the Country Report Korea that was compiled for the CIVICUS civil society index (Joo, Lee and Jo 2006).

In sum, Korean CSOs have achieved high scores concerning their values and the impact of their activities. This is despite the fact that their structure is comparably weak, and they have to operate in a relatively unfavorable political and socio-economic environment. In other words, Korean CSOs appear to have 
high effectiveness, achieving good result despite relatively poor "input." This effectiveness makes Korean CSOs an interesting study if we are looking for possible lessons for developing countries and developmental theory.

In the CIVICUS report, civil society in Korea scores highest in the "value" category (2.3 out of 3 points) that evaluates the goals and means of CSOs from a normative standpoint. Korean CSOs have laudable goals of democracy, environmental protection, economic justice, welfare, and development even though they often disagree on how to achieve them. Extremist CSOs that openly support a return to military dictatorship or promote racism and hatred are practically nonexistent. Left-wing extremist that openly support the Kim Jong Il dictatorship in North Korea are small and play virtually no role in shaping public discussions. Korean CSOs try to achieve their goals through non-violent activity. Korea is widely known for violent street protests that had been justified and even necessary during the struggle against the dictatorship, but are counterproductive in a democratic environment in which the freedom of association and assembly is guaranteed. In fact, CSOs have played an important role in civilizing protests compared to sometimes more violent protests of labor union, farmers', veterans', and other occupational association. A good example has been the candle light protests against US beef imports that, regardless of their questionable goals, remained largely peaceful (Kim and Kim 2009). Violence has been pushed to the fringes of civil society despite the often very restrictive and even provocative restriction imposed on protests by the police (see below).

The second highest score that CSOs in Korea have received was in the "impact" category (1.9 out of 3 points), which means that Korean CSOs are relatively successful in their work. They are particularly successful in influencing political decisions and policies. In the CIVICUS studies, Korea received a score of 2.5 out of 3 in this sub-category. This is one of the highest scores in any sub-category and is remarkable in international comparison. Korean CSOs have become an important factor in the Korean political system that the government cannot ignore. CSOs successfully interact with "official" political institutions either through cooperation or through confrontation, as we will discuss later.

One of the most prominent campaigns of Korean CSOs, notably the PSPS, has been the minority shareholder campaign. (Choi and Cho 2003; Kalinowski 2008; Kim 2007; PSPD 2008; Rho 2007) Minority shareholder activities are an excellent case study in understanding how civil society activities substituted the withdrawing developmental state. During the prime time of the developmental state, big business was merely a junior partner of the government. The government controlled the chaebols through industrial policies, strict regulations and state run banks (Woo-Cumings 1991). Economic liberalization and the privatization of the financial system since the 1980s made this kind of direct control obsolete. Liberalized from direct control, the chaebols started a reckless international expansion strategy with money borrowed from international banks-a strategy that directly 
led to the Korean Financial Crisis of 1997/98 (Chang, Park and Yoo 1998; Jeong 2004). It was, thus, natural that the re-regulation of chaebol activities and improved corporate governance was on the agenda of the new Kim Dae Jung government. The new government opted for a combination of stricter state regulations of chaebols, expose them to market forces, and check their power by CSOs. Most importantly, the government imposed a debt to equity limits of $200 \%$, opened equity markets to foreign investors, and an improved minority shareholder rights to control corporate management. Alternative options like German style participation of employees in controlling management were discussed but dismissed. CSOs played an important role in the plan to improve management control by shareholders. Firstly, by engaging as "policy entrepreneurs" (Kim and McNeal 2005) CSOs like PSPD brought up the issue of minority shareholder rights. They also influenced the government in its decision to opt for US style shareholder capitalism instead of German or Japanese style corporatism. Secondly, they followed this strategy by influencing public opinion against the chaebols, which was relatively easy because big business was widely blamed for the economic calamities. By influencing public opinion, they countered lobbying attempts by the chaebols to avoid stricter control. Thirdly, after improved minority shareholder rights were written into law, minority shareholder CSOs helped implement the law by using small shareholdings to managements that they perceived as corrupt or incompetent.

Another successful campaign to balance the overwhelming power of big business was the anti-corruption campaigns during the general elections of 2000 and 2004. During the campaign more than 450 CSOs formed the Citizens' Alliance for the General Election (CAGE) and published black lists of corrupt politicians. Many of them received money from one or more of the big business groups that try to influence political decisions directly instead of relying solely on achieving a hegemonic position within the civil society. Of the 113 potential candidates that were blacklisted, 11 did not seek nomination and 48 failed to be nominated by their party. Before the election CAGE published a new blacklist containing 86 candidates, of those 59 lost the election (Shin 2003).

Consumer groups have only started to fight back against the monopolistic chaebols that are able to use their control of the Korean market to exploit domestic consumers in order to subsidize exports and facilitate international expansion. Korean consumers have long coped with high consumer prices and the poor quality of products. The government has refrained from direct interventions like price controls and has been reluctant to break up monopolies in order to facilitate the expansion of the chaebols as "global players." Instead, with ideological support from the "new right" the government has tried to limit the market power of chaebols by increasing competition from imports through free trade agreements and lower tariffs. The first victory of new right CSOs was a switch to free trade ideology (if not yet practiced) in Korea after decades of protectionism 
of the domestic market, and "Buy Korean" campaigns. However, free trade and market forces alone will not automatically improve the quality of products, nor will they reduce prices if domestic monopolies use their market power to impede the retail sale of imported products. The increase of market coordination can thus only help to improve the general welfare, if other mechanisms like government regulations and an active civil society are in place.

Korea receives lower scores in the evaluation of the structure of CSOs (1.5 out of 3), and the legal and socio-economic environment in which they operate (1.6 out of 3).

Even though Korea is a democracy, the legal and political environment for CSO activities remains problematic. Particularly the very restrictive association laws prevent the organization of effective protests. Even more than 20 years after the end of the military dictatorship, demonstrations are frequently declared illegal by the government for minor reasons like potential traffic jams. Weak protection of data privacy and strict defamation laws restrict freedom of speech, making it risky to criticize the government, particularly on the Internet. In Korea, popular websites are required to verify the identity of their user when they post comments. In 2009, there were two highly publicized cases when the TV producer of MBC's "PD Diary" and a blogger ("Minerva") were arrested because prosecutors accused them of deliberately spreading rumors and false statements (Financial Times, 8 January 2009 and Joong Ang Daily, 27 March 2009).

The societal environment is unfavorable because most Koreans restrict their social life to extended family and peer groups like colleagues, classmates, and alumni associations. Social capital within these groups is extremely high, but hardly develops with individuals or groups that are outside. General levels of "inter personal trust" (Inglehart 1999), public spirit, and tolerance remain low, which impedes the formation of CSOs that cross peer group borders.

The unfavorable environment has negative consequences for the structure of CSOs. The associations remain volatile and depend on a small core of mostly intellectual activists, due to the lack of long-term engagement by citizens. CSOs are strongly influenced by intellectuals that tend to prefer technocratic solutions and neglect internal democracy. The CSOs, depending on a few activists, are also vulnerable to cooptation by business and government institutions. Lack of funds from membership fees, contributions and government resources are serious challenges that leaves CSOs vulnerable to influence from powerful donors and corruption.

While the level of organization in the broad population remains comparably weak, spontaneous volunteering is very common. Good examples are the gold collecting campaign during the 1997/98 Asian financial crisis, and the recent cleaning up of the Yellow Sea oil spill in 2007/08. These campaigns show that civic engagement is possible and that widespread miscrust and atomization can 
be overcome. It remains an open question how spontaneous engagement often triggered by patriotic campaigns can be transformed into long-term civic engagement.

\section{TOWARDS A DEVELOPMENTAL SOCIETY? STATE-CIVIL SOCIETY SYNERGY AND CONFLICT}

The formation of a developmental society by CSOs that supplement the coordination mechanisms of state and market has at least five dimensions. These are the substitution of weak political parties, state-civil society synergy, providing a recruiting pool, struggle for hegemony, and the channeling of discontent. The process of forming a developmental society is neither linear nor harmonious, but rather a reaction to the weaknesses of the established intermediary institutions. It is thus not surprising that the relationship between state and civil society organizations is characterized by synergy as well as conflict.

First, CSOs and the state institutions (including political parties) have conflicting visions or ideologies about the normative goal of reforms. They compete not just over concrete policies, but also over the general vision for a better society. In Korea, these ideological conflicts are very strong because civil society is dominated by politicized advocacy CSOs. These CSOs can be described as surrogate parties with a huge membership, covering a wide range of issues, and having clear ideological direction. The large multi-issue CSOs like PSPD and CCEJ have an anti-business orientation with the goal of transforming Korea into a social democracy. The new right, on the other hand, has a pro-business free market ideology, pushing the government to limit state intervention in the economy. The explicit political orientation of CSOs can be explained by the origin of $\mathrm{CSO}$ in the fight against the military dictatorship as part of the democracy movements. The concrete activities of the organizations are thus not just the reaction to dissatisfaction with certain government activities, but also an expression of their broader political goals and ideologies. The large multi-issue CSOs like PSPD and CCEJ in Korea fill the gap of a missing social democratic party that occupies this part of the political spectrum in most advanced democracies. The new right substitutes a classical liberal-conservative party like the Republican Party in the US that combines economic liberalism with conservative political values, but without the open authoritarian nationalist tendency of the old right. CSOs are an expression of the weakness of the party system in Korea. CSOs fill the political vacuum that is left by dysfunctional parties and politicians that dominate the state through personal networks and money politics. CSOs compete with government, politicians, and parties over the right policies and an appropriate vision for Korea. Until now, CSOs have not made the step to transform themselves 
from CSOs to political parties. Consequently, the political conflict that exists between different political parties in most democracies finds its equivalent in the conflict between the "official political system" and the CSOs.

Second, CSOs have the function to channel inevitable dissatisfaction about government politics. Politics is always about choosing certain policies above other policy options. Even if the chosen policies are aimed at achieve the common good, it is inevitable that there are different opinions about how the common good can be achieved. Nearly all policy choices create winners and losers but it should be the role of the government to maximize winners and minimize losers of policy changes. Advocacy and protests by CSOs against government policies are an important way in a democratic country to voice dissatisfaction besides the general elections. This is particularly important in countries that have few elements of direct democracy (initiative, referendum, recall) like Korea. The CSOs' competition with official state sectors over the appropriate plan and vision is a source of synergy-at least when this competition is not completely antagonistic. CSOs enrich the political process by broadening the political spectrum and political choices. Existing interests within the society always find a way to express themselves. If the political representation in official institutions is blocked, the interests will organize in the form of CSOs. If the organization in CSOs is blocked or ineffective, the interests will be pursued by other means like corruption and violence. From this perspective, CSOs are a desirable way to channel interests in a non-violent and transparent way. The CSOs organize support and opposition for or against policies. Through these activities, they inform the government how to draft regulations that have the highest possible support. By organizing interests, the CSOs provide a service for the government in the sense that it allows discussion on policies with these organized interest groups. For the government this is a great advantage, because it has a counterparty to negotiate, while unorganized opposition against policies in the form of spontaneous "insurgencies" and passive resistance is much harder to handle constructively.

Third, CSOs also provide governments, politicians, and parties with a constant stream of ideas ("policy entrepreneurs"), information, and expertise about concrete policies. CSOs often have a high degree of technical knowledge. The major CSOs have a substantial number of full time staff (KFEM approximately 250, PSPD approximately 50, CCEJ approximately $34^{4}$ ) that are supported by experts like professors, lawyers, and journalists (CCEJ 2009; KFEM 2009; PSPD 2009). Their ideas and specialized knowledge can indicate need for government action and provide technical advice. For example, environmental organizations often have better information than government bureaucrats on how to protect the environment, and minority shareholder movements are better informed on how to regulate and control the management of a company in which they have invested. 
CSOs are also important in implementing and enforcing policies. The government can pass laws that protect the environment or improve the rights of minority shareholders, but to enforce the laws it needs cooperation with CSOs. New laws and establishments of rights as such do not change much, if nobody claims the rights or report violation of the law. Thus, new minority shareholder rights need minority shareholder organizations that claim the rights enshrined in the new regulations (Kalinowski 2008). Similarly, a new environmental law needs active environmental CSOs that expose violators.

Fourth, CSO experts are advisers to the government or serve in commissions. The increase of commissions under the Roh Moo Hyun administration even led to critical remarks about the "Commission Republic" that diverts deliberations from democratically elected institutions. CSOs widen the pool of professionals that can serve in government institutions. This is particularly important for parties that have been excluded from government for a long time and thus lack experienced experts. Indeed the two progressive governments of Kim Dae Jung and Roh Moo Hyun saw a surge in representatives from progressive CSOs entering government positions. The new conservative President Lee Myung Bak seems to continue this tradition except that he turns to new right CSOs as a recruiting base. The role of $\mathrm{CSO}$ s as a pool for government positions is a double-edged sword for $\mathrm{CSO}$, because through the co-optation by the government they lose some of their creditability of being an independent actor.

Lastly, civil society organizations have improved state capacity by balancing the overwhelming power of big business. By state capacity, we mean the ability to escape state capture by powerful interest groups and the ability of political decision makers to choose between different policy options. CSOs have enriched the extended civil society that used to be dominated by powerful interest groups like business associations (and to a far lesser extent by labor unions). Big business became increasingly hegemonic in the political discussion since democratization reduced the authoritarian control of the state. That is why this first phase of democratization from 1987 to 1997 is often referred to as the "Chaebol Republic." Civil society organizations dealing with economic and social justice or environmental issues are at least to some degree able to balance the overwhelming power of big business. A diverse civil society prevents state capture by a few powerful interests and opens up a political space-a civil society arena-in which the political decision makers are able to decide politically which policies are most adequate to serve the common good. In some sense, CSOs gave the state back some of the "embedded autonomy" (Evans 1995) it possessed during the authoritarian rule until the 1980s. While this kind of authoritarian autonomy was embedded in the partnership between chaebol and state, the democratic autonomy of today is embedded in the competition of diverse interests within the Korean civil society that evolved due to the rise of the Korean civil society movement. 


\section{LESSONS FROM KOREAN CIVIL SOCIETY FOR DEVELOPING COUNTRIES}

Extracting possible lessons from CSO development in Korea offers many potential benefits, but has to consider at least two problems. First, Korea is by far not a "best practice" case of civil society activity. Korean CSOs are facing many challenges as we have seen earlier in this paper. Second, other countries have different socio-economic and political environments. Institutions cannot simply be transferred from one country to the other and imposed on a society that is structured differently. All possible lessons have to be evaluated with this in mind. Korea cannot be a role model for other countries, but from describing Korean development and CSOs, governments and scholars in other countries can extract a conclusion for their own concrete political economic environment. Lessons can be learned from other countries but CSOs have to operate in the concrete political economic context of each country. It is not possible to simply transfer institutions from one country to the other even when these institutions would be objectively beneficial.

Despite these limits, we believe that a couple of important lessons can be learned from Korean CSOs. As we have seen above, Korean CSOs represent progressive goals and high values for which they are highly respected by the population. Korean CSOs have a strong impact despite serious shortcomings in their structure and the socioeconomic, legal, and political environment. Korean CSOs produce a remarkable "output" with a relatively poor "input." This effectiveness makes them very interesting objects to study for development scholars, because CSOs in most developing countries operate in environments that are at least as unsupportive as in Korea. While CSOs in Europe and North America might be more active and successful in achieving their goals, they also operate in a more favorable political and socio-economic environment. Learning from these "best practice" cases would require the construction of a more favorable environment in developing countries first. A task that is obviously far more difficult than to learn how to operate CSOs in a less favorable environment. Thus, studying Korea as a "second best practice" might be more beneficial for developing countries.

Strong multiple issue advocacy based CSOs are a distinct feature of the Korean civil society. Establishing and supporting such organizations in other developing countries could have huge benefits. Most developing countries do not lack CSOs altogether. On the contrary, most developing countries have very active civil societies with organizations that address concrete problems like poverty, health, lack of access to finance, security, and so forth that are active in most developing countries. These CSOs provide services that the state and the market are not able or not willing to provide. However, in contrast to their Korean counterparts they are not successful in pressuring their governments to provide these services 
or improve the effectiveness of government services. Single issue CSOs have not made the step into the political terrain or at least they have not been successful in influencing policy decisions. As we have seen above, widening the policy choices for the government and influencing its decision have been the strength of Korean CSOs. Learning from the Korean experience promises to be highly beneficial. However, there are major obstacles for CSOs in many developing countries to copy the Korean example.

First, in contrast to Korea, in some developing countries, particularly those that face internal violent conflicts, CSO are organized along nationalist, religious, or ethnic lines. Such organizations interpret governance problems not as challenges that can be overcome by a negotiation process, but rather as the result of domination by "foreign" or "impure" forces. Such militant "CSOs" do not aim to change and improve the state by influencing government decisions, but they aim at replacing the government and even revolutionize the political system as such. ${ }^{5}$ These CSOs are not surrogate parties like the Korean advocacy CSOs, but they are indeed political parties even if they do not perceive themselves as such. They do not follow the civil society ideology to "change the world without taking power," but want to conquer power, with some of them at any cost. Extremists groups like the conflicting religious groups in Iraq, the tribal groups in Afghanistan and the warlords of Sudan even accept terrorism as a legitimate means in their political struggle. They deliberately try to reduce welfare and worsen the situation of citizens in order to create a revolutionary situation that would allow them to conquer power. In this kind of environment, the problem is that extremist "CSOs" have crowded out the state, which has not been even able establish its fundamental basis by monopolizing the use force within its territory (Weber 1980).

Second, even in the absence of extremist "CSOs," the problem of developing countries is often not a weak civil society but a weak state (Migdal 1988; Pearce 2000; Whaites 1998). The state remains the main actor to manage economic and social development. Even the most radical promoters of free markets admit that markets need sophisticated institutions to function properly. Countries that have weak states or even failed states that simply leave development to "the market" seldom develop successfully. As we have seen throughout this paper, the success of CSOs in Korea depended on their interaction with the state. CSOs cannot achieve changes alone, because they cannot make policies universally valid and enforce them with the monopoly of the use of force the state possesses. The state-civil society synergy is a result of conflict and cooperation between state and CSOs. In countries where there is no functioning state, there will also be no synergy. In weak states, it is more likely that CSOs will take over functions that are usually the domain of state institutions like schools, hospitals, social welfare, and even security. There is even the danger that CSOs further undermine the legitimacy of the state and undermine state capacity building 
because they occupy classical responsibilities of the state. This is particularly problematic if foreign development $\mathrm{CSO}$ s with substantial funding have the ability to outspend and crowd out a cash-strapped government. Unfortunately, the analysis of the role of CSOs in Korean development does not offer any lessons for extremely weak or even failed states. ${ }^{6}$

However, the Korean case offers many insights for countries that experience a weakening state due to economic liberalization, deregulation, and globalization. Like the Korean developmental state since the 1980s, many states lose regulatory power and see their capacity to govern development being reduced through the forces of globalization and the dominance of financial investors and big business. The strategy of a "traditional" developmental state like Japan, Taiwan, and South Korea until the 1980s is not feasible in the "age of globalization." Even socialist developmental states like China and Vietnam allow more and more room for private economic initiative. The retreat of the state from economic planning leaves a gap that cannot be filled by "the market" alone. CSOs will have to play an important role in order to govern complex and decentralized societies by organizing interests and by working as intermediary institutions between the society and the government. CSOs that could fill this gap would be the most obvious beneficiaries from an observation of the Korean case.

Third, the political environment for CSO activities in many developing countries is worse than in Korea. Many developing countries are authoritarian regimes or at least their quality of democracy is below the level of Korea. The civil society organizations in Korea are a product of democratization, and evolved out of the student and democratization movement that successfully brought down the military dictatorship in 1987. CSOs can only flourish and develop their full potential in democratic states. The full development potential of state-civil society synergy can unfold best in strong democratic states with strong civil societies (Evans 1996; Heller 1996). The widespread conception of the advantages of authoritarian regimes in development is a myth, and it rather seems that economic development and democracy are mutually beneficial and re-enforcing (Sen 1999; Wrage 1997). It is probably true that an industrialization of the pace Korea experienced would be impossible in a democracy due to the necessary brutal social changes that it required. However, it is highly questionable if such a development is desirable or would be even possible for developing countries today. Even though civil society can flourish only in a democracy, they can play an important role in authoritarian regimes as well. As we have shown in this paper, CSOs play an important role to improve governance and integrate citizens into the political decision making process. Because authoritarian governments lack the institutions of free and fair elections, the potential benefits from CSOs for authoritarian governments is even higher than for democratic governments. Authoritarian governments can profit from political and specialized information provided by $\mathrm{CSO}$ s without fearing to lose power. Contrary to democracy 
movements and opposition parties, CSOs are not automatically a direct challenge to the party or group in power. CSOs can even help to stabilize authoritarian governments, if they effectively improve the quality of governance. CSOs can help stabilize all kinds of existing governments regardless if they are democratic or authoritarian with the exemption of totalitarian regimes that see any kind of non-government organizations as a direct challenge. This character of CSOs to stabilize existing regimes is the reason why radical critics like Antonio Gramsci saw civil society primarily as the arena where the ruling class is dominating the subordinate classes through consent and cultural hegemony (Gramsci 1992).

It is important to give up the illusion that CSOs automatically promote democratization. The good news is that this is exactly why authoritarian governments are far more willing to accept and work with CSOs than with opposition parties that have the ultimate goal of challenging the government and becoming a governing party themselves. At the same time, strong CSOs are a double-edged sword for authoritarian governments. They help to solve problems and improve governance and are thus a stabilizing force for authoritarian regimes. However, they bring together and organize people, creating a potential for empowerment and politicization that could result in challenges to the government in the long run. CSOs have the potential to build up an alternative society within the existing one that could be the seed for the new post-authoritarian society. They could also provide a recruitment pool for professionals of future democratic governments.

\section{CONCLUSIONS}

Korean CSOs have a considerable, positive impact on Korean social and economic development despite a relatively poor organizational structure, and many socioeconomic and legal obstacles. Korean CSOs have been effective in a relatively unfavorable political and social environment. In some sense, Korean CSOs are an expression of poor political institutions with the authors having characterized them as surrogate parties. They fill the vacuum left by the dysfunctional party system, particularly on the progressive side of the spectrum. CSOs act as intermediary institutions between the atomized interests in the society and state institutions. They help to organize interests that were neglected before. In particular, they helped to challenge the collusion between big business and politics that has dominated Korean politics. By balancing big business interests and the resulting political corruption, CSOs opened a political space that allowed the government to maintain some distance to the chaebols. The state regained some of the autonomy it lost through economic liberalization and the ever-increasing market dominance of the chaebols since the 1980s. The growing counterweight of CSOs had its breakthrough with the 1997/98 financial crisis that was rightly blamed on chaebol mismanagement. The crisis facilitated the rise of CSOs and allowed the election 
of two progressive and chaebol critical presidents that governed from 1998 to 2008. During this period, CSOs were active as policy entrepreneurs that provided ideas and support for the government, also acting as a recruitment pool for government officials. Despite the state-civil society synergy, the relationship between CSOs and state institutions were far from harmonious. Due to the weakness of political parties and labor unions to act as intermediary institution that represent the concerns of ordinary citizens, it was up to the CSOs to articulate dissatisfaction with the political and economic elite.

The impressive impact of Korean CSOs despite the challenges that they are facing makes them a very valuable object to study for scholars of development. We believe that the potential for a mutual learning process between Korean $\mathrm{CSO}$ and CSOs in developing countries is immense. While European and American $\mathrm{CSO}$ are able to offer money and consultation, Korean CSOs are able to contribute practical experience in how to operate in a society that is still in a relatively early stage of democratization, and that still shares many of the economic and political problems of developing countries.

While there are many possible lessons from the Korean case, it can never serve as a role model for other developing countries. Institutions like CSOs can only be understood in the concrete historical context in which they developed, and cannot be simply transferred to a different country with a different political economic environment. Most developing countries do not primarily suffer from weak CSOs, but they suffer from weak or failed state institutions. While CSOs can compensate some of the shortcomings of state institutions, the biggest advantages can be achieved through interaction and synergy between CSOs and state institutions. Finally, many governments fear CSOs because, from their point of view, they bring the advantage of state-society synergy at the cost of the empowerment of citizens. For authoritarian governments, CSOs are a double-edged sword. The potential of CSOs to improve the quality of governance might stabilize authoritarian governments, but their potential to organize and empower people is able to undermine their power in the long run.

\section{REFERENCES}

Barber, Benjamin R. 1995. Jibad vs. McWorld. 1st Edition. New York: Times Books.

Bratton, Michael. 1989. Review: Beyond the State: Civil Society and Associational Life in Africa. World Politics 41(3): 407-430.

CCEJ. 2009. Citizen Coalition for Economic Justice Webpage 2009. http://www.ccej.or.kr/english/.

Chang, Ha-Joon, Hong-Jae Park and Chul Gyue Yoo. 1998. Interpreting the Korean crisis: financial liberalisation, industrial policy and corporate governance. 
Camb. J. Econ. 22(6): 735-746.

Choi, Woon-Youl and Sung Hoon Cho. 2003. Shareholder activism in Korea: An analysis of PSPD's activities. Pacific-Basin Finance Journal 11(3): 349-363. CIVICUS. 2009. CIVICUS-World Alliance for Citizen Participation 2009. www.civicus.org.

Evans, P. 1996. Government Action, Social Capital and Development: Reviewing the Evidence on Synergy. World Development 24(6): 1119-1132.

Evans, Peter B. 1995. Embedded autonomy: states and industrial transformation. Princeton, N.J.: Princeton University Press.

Gramsci, Antonio. 1992. Prison Notebooks: Columbia University Press. Han, Yuna. 2007. The New Right. Political Winds in South Korea. Harvard International Review 29(1).

Heinrich, Volkhart. 2004. Assessing and Strengthening Civil Society Worldwide: A Project Description of the CIVICUS Civil Society Index: A Participatory Needs Assessment and Action-Planning Tool for Civil Society. CIVICUS Civil Society Index Paper Series 2(1).

Heinrich, Volkhart. 2007. CIVICUS global survey of the state of civil society. Vol. 1. Country profiles. Bloomfield, CT: CIVICUS: Kumarian Press.

Heller, Patrick. 1996. Social capital as a product of class mobilization and state intervention: Industrial workers in Kerala, India. World Development 24(6): 1055-1071.

Inglehart, Ronald. 1999. Trust, well-being and democracy. In Democracy and trust, ed. Mark E. Warren: Cambridge University Press.

Jeong, Seung-il. 2004. Crisis and restructuring in East Asia: the case of the Korean chaebol and the automotive industry. New York: Palgrave Macmillan.

Joo, Sungsoo, Seonmi Lee and Youngjae Jo. 2006. Civicus Civil Society Index Report for South Korea. The Explosion of CSOs and Citizen Participation: An Assessment of Civil Society in South Korea. Seoul.

Kalinowski, Thomas. 2008. State-Civil Society Synergy and Coopration: The Case of the Minority Shareholder Movement in Korea. Korea Observer 39(3): 339-367.

Kalinowski, Thomas and Hyekyung Cho. 2009. The Political Economy of Financial Market Liberalization in South Korea: State, Big Business, and Foreign Investors. ASIAN SURVEY 49(2): 221-242.

KFEM. 2009. Korean Federation for Environmental Movement Webpage 2009. http://english.kfem.or.kr.

Kim, E. M. 1993. Contradictions and limits of a developmental state: with illustrations from the South Korean case. Social Problems: 228-249.

Kim, Eun Mee. 1997. Big business, strong state: collusion and conflict in South Korean development, 1960-1990. Albany, NY: State University of New York Press.

Kim, Hyun Rae. and David K. McNeal. 2005. NGOs as policy entrepreneurs in South Korea in Civil Life, Globalization, and Political Change in Asia: Organizing 
Between Family And State, ed. Robert Paul Weller. London and New York: Routledge.

Kim, S. 2001. The Politics of Democratization in Korea: The Role of Civil Society. International Review of Public Administration 6(2).

Kim, W. 2007. Shareholder Activism: Corporate Governance Reform in Korea-By Han-Kyun Rho. Corporate Governance: An International Review 15(6): 1480-1481. Kim, Yong Cheol and June Woo Kim. 2009. South Korean Democracy in the Digital Age: The Candlelight Protests and the Internet. Korea Observer 40(1): 53-83.

Koo, H. 2002. Civil Society and Democracy in South Korea. The Good Society 11(2): $40-45$

Lee, Yoonkyung. 2009. Democracy without Parties? Political Parties and Social Movements for Democratic Representation in Korea. Korea Observer 40(1): $27-52$.

Liberty Union. 2009. Founding Declaration 2009. http://www.486.or.kr/english/sublc.php.

Migdal, J. S. 1988. Strong societies and weak states: state-society relations and state capabilities in the Third World: Princeton University Press.

Pearce, J. ed. 2000. Development, NGOs, and civil society: the debate and its future.

Polanyi, Karl. The great transformation the political and economic origins of our time (2nd Beacon Paperback). Beacon Press 2001. Available from http://site.ebrary.com/lib/brown/Doc?id=10014733 View electronic book; access limited to Brown University users. Copyright law applies; printing more than $10 \%$ of any book, online or print, may be a copyright violation. Ebrary allows you to print up to 40 pages at one time.

PSPD. 2008. Minority Sharebolders Campaign History 2008.

http://eng.peoplepower21.org/archive/shareholder_history_1.html.

PSPD. 2009. People's Solidarity for Participatory Democracy Webpage 2009. http://blog.peoplepower21.org/English.

Putnam, R. D. 1995. Bowling alone: America's declining social capital. Journal of Democracy 6: 65-65.

Rho, Han-Kyun. 2007. Sharebolder activism: corporate governance reforms in Korea. New York: Palgrave Macmillan.

Sen, Amartya Kumar. 1999. Development as freedom. 1st. Edition. New York: Knopf.

Shin, Eui Hang. 2003. The role of NGOS in political elections in South Korea: the case of the citizens' alliance for the 2000 general election. ASIAN SURVEY 43(4): 697-715(619).

Silver, B. J. and G. Arrighi. 2003. Polanyi's Double Movement: The Belle Epoques of British and US Hegemony Compared. Politics and Society 31(2): 325. Weber, Max. 1980. Wirtschaft und Gesellschaft: Grundriss d. verstehenden Soziologie. 
5., rev. Aufl. Edition. Tübingen: Mohr.

Whaites, Alan. 1998. NGOs, Civil Society and the State: Avoiding Theoretical

Extremes in Real World Issues. Development in Practice 8(3): 343-349.

Woo-Cumings, Meredith. 1991. Race to the swift: state and finance in Korean industrialization. New York: Columbia University Press.

Woo-Cumings, Meredith. 1999. The developmental state. Ithaca, N.Y.: Cornell University Press.

World Bank. 1997. World Development Report 1997: The State in a Changing World. Washington D.C.: Published for the World Bank, Oxford University Press.

World Bank. 2005. Issues and Options for Improving Engagement Between the World Bank and Civil Society Organizations. Washington DC.

Wrage, S. 1997. Exploding the Myth of the Authoritarian Advantage. Mershon International Studies Review 41(2): 302-304.

\section{ENDNOTES}

'When we talk about civil society here we follow the definition of CVICUS that defines civil society as "the arena, outside of the family, the state, and the market where people associate to advance common interests." (Heinrich 2004: 13) Generally speaking civil society organizations (CSOs) are the institutions in which these associations take place.

2 We, thus, exclude pure service providing $\mathrm{CSO}$ s that do not have the intention to organize interests or influence public opinion. We also use the term CSO in this paper in differentiation to hybrid organizations like labor unions, employer's organizations/think tanks and political parties even though we acknowledge that there are hardly any "pure" civil society organizations.

${ }^{3}$ The Civicus Civil Society Index assesses the state of civil societies in 54 states. It uses 74 indicators in four dimensions (structure, environment, values and impact). The score of each indicator ranks from 0 (worst) to 3 (best). The evaluation is done by a National Index Team consisting of civil society experts and researchers. The NIT writes the country report and is advised by the National Advisory Group that consists of civil society stakeholders. The report and the scores are based on secondary data collection, regional stakeholder consultation, a population survey, a media review and expert assessments (Heinrich 2007).

the number for the CCEJ is the full-time staff in the main Seoul office without the staff of the regional offices.

This is not to say that this is always negative. Many authoritarian governments deserve to be toppled. However, the lessons that could be learned from Korea are those of the 1980s and would be beyond the scope of this paper.

${ }^{6}$ Unless, of course, we would go back to the immediate post-World War 2 time, which would be beyond the scope of this paper. 